\title{
NOTAS SOBRE TRADIÇÃO E RUPTURA NO RENASCIMENTO E NA PRIMEIRA MODERNIDADE ${ }^{1}$
}

\author{
Prof. Dr. Modesto Florenzano \\ Depto. de História-FFLCH/USP
}

\begin{abstract}
RESUMO: Estas notas tem por tema a questão da tradição e da ruptura, da continuidade e da mudança na Europa Moderna. Mais precisamente, como os sujeitos históricos, e a historiografia viram, sentiram e interpretaram a continuidade e a ruptura.
\end{abstract}

ABSTRACT: These notes examine the issue of tradition and rupture, of continuity and change in Modern Europe, and, more precisely, how the historical agents and the historiography viewed and interpreted this issue.

PALAVRAS-CHAVE: Renascimento, Medicval, Antigüidade, Clássico, Moderno, Auto-Realização

KEYWORDS: Renaissance. Medieval, Antiquity, Classics, Modern, self-accomplishment

Aparentemente nāo há nenhum motivo para aproximar o historiador suíço Jacob Burckhardt (18181897) do pensador e político francês Alexis de Tocqueville (1805-1859). Contudo, não se pode prescindir dos seus nomes quando se aborda a questão da tradição e da ruptura na época moderna, que é o que se pretende fazer aqui. Embora não tenham sido eles os criadorcs, ou os primeiros a fazerem uso, dos termos "Renascimento" e "Antigo Regime", foram eles os primeiros que elevaram estes termos à categoria de conceitos que balizam e definem a primeira modernidade européia. E o fizeram com tal maestria, para não dizer genialidade, que não se pode, desde então, tratar historicamente do Renascimento e do Antigo Regime, vale dizer, do início e fim da primeira modernidade, sem passar necessariamente por Burckhardt e Tocqueville.

Em outras palavras, com suas respectivas obrasprimas $A$ Cultura do Renascimento na ltália e $O A n$ tigo Régime e a Revolução, publicadas quase ao mesmo tempo (a primeira em 1860 e a segunda em 1856), Burckhardt e Tocqueville, deram aos termos "Renascimento" e "Antigo Regime" a condiçāo e a altura de conceitos, de categorias históricas, possuidoras a um só tempo de unidade e abrangência, de

1. Este ensaio ś uma verș̄o ligeiramente ampliada da aula escrita apresentada para o concurso de efetivação prestado na F.F.L.C.H. em dezembro de 1995. 
conteúdo e forma, de espaço e tempo. $O$ que Peter Gay disse de Burckhardt, também vale para Tocqueville, porque ambos, com suas obras, acima mencionadas, estavam "criando de uma só feita o que a poucos -pouquíssimos- historiadores é dado criar: um novo campo de estudos"(GAY, 1974, p.137)

Coube ao historiador holandês Johan Huizinga (1872-1945) o mérito de ter demonstrado -no ensaio O problema do Renascimento(1920)- que a palavra Renascimento, indicando um determinado perfodo da civilização, entrou em uso, pela primeira vez, nos ćŕculos intelectuais parisienses, na década de 1820. "Balzac -afirma Huizinga- tinha já usado a palavra Renaissance como conceito autônomo da história da civilização, na novela Le bal de Sceaux, de dezem-

2. Embora a página citada do livro de Peter Gay, $O$ Essilo, na Hishiria, seja da ediçăo brasileira, a data ê da edição original; será esse o procedimento aqui adotado, qual seja, o de citar sempre a data da ediçảo original e, quando existt, a página da ediçăo em língua portuguesa. Nāo deixa de ser interessante constatar que tanto Burckhardt, quanto Tocqueville, afirmam quase que a mesma coisa nas introduçōes as suas obras. Assim, enquanto o primeiro declara: "E no verdadeiro sentido da palavra que esta obra carrega o título de um mero ensaio", o segundo: "O livro que publico neste momento não es uma história da Revolução, história que já foi feita com tanto brilho para que eu pense em refazê.la; é um estudo sobre esta Revoluçäa". Ora. dado que o estudo de Tocqueville (e ao dizer estudo é como se (ivesse dito ensaio) trata mais do Antigo Regime do que da Revoluçđoo propriamente dita, ele também. como Burckhardt, desbravou um terriısrin inex plorado. Mas ño terminam á as aproximaçōes que podem ser feitas entre Burckhardt e Tocqueville. Assim, se o primeiro adverte o leitor para a "subjetividade" de seus "juizos", para o fato de que "os mesmos estudos realizados para este trabalho poderiam. nas mãos de outrem, facilmente experimentar não apenas utilização e tratamento totalmente dis. tintos, como também ensejar conclusōes substancialmente diversas"; o segundo năo deixa de advertir que "espera ter escrito o presente livro sem preconceitos mas não pretende tê-lo escrito sem paixão". Também a visðo de história de ambos se asseme- bro de 1829, onde de uma das personagens é dito que: 'Elle raisonnait facilement sur la peinture italienne ou flamande, sur le Moyen-Âge ou la Renaissance'"'(p.229). E a seguir Huizinga lembra que, em 1855, portanto, cinco anos antes de aparecer o livro de Burckhardt, o historiador francês Jules Michelet publicava a sélima parte de sua Histoire de la France, que tinha por subtítulo Renaissance. E sobre a interpretaçño que Michelet fez do Renascimento. Huizinga constata, nảo sem uma certa perplexidade, que: "Michelct não distingue Reforma de Renascimento: um e outro sĩo para cle felizes alvoradas do ideal do Iluminismo. E entre os representantes do grande despertar, a prescindir de Colombo e Galileu, nāo nomeia nenhum italiano!"(p.232).

Iha; assim, o que Peter Gay afirma no final de sua apreciaçăo sobre Burckhardt, vale igualmente para Tocqueville: uma visão "essencialmente ambivalente" da história; uma "concepç̆̋̆o dualista do individualismo exemplifican vividamente sua conviç̧⿸丆o de que a civilização s fundamentalmente problemática e tremendamente frágil"(p.165-166). Em suma, nem Burckhardt nem Tocqueville estavam possufdos, como tantos em sua ćpoca. por uma concepç̃o de história cujo desfecho, desejóvel, para năo dizer feliz, poderia ser previamente antevisto. Com seus, respectivos. conservadorisıno, pessinismo e relativismo, ambos viam a historia como um campo aberto. conflagrado e indeterminado, onde os indivfduos tanto podtriam cair no barbáric quanto elevar-se na civilização. Deve ser tembrado, fimalmente. que o pioneirismo de Burckhardt e Tocqueville, como historiadores. reside tanto nos objetos que criaram, nos territórios novos que desbravaram, quanto na maneira, no procedimen. to, absolutamente original, que adotaram e que se manifesta. por exemplo, no fato de ambos nato terem feito o que praticamente lodos os historiadores então faziam, ou seja. uma história narrativa e política (institucional). Do primeiro. pode-se dizer que. sua história-cultural antecipa a história social e das mentalidades; e do segundo, que sua história-sociológica, ou sociologia-historica, antecipa a história preocupada com as forças profundas, subjacentes, estruturais e de Jonga-duração; daí o caráter extremamente atual das duas obras. 
Que o desconhecimento então existente sobre o Renascimento e o nacionalismo tenham impedido Michelet de ver que foram os italianos os criadores do Renascimento, compreende-se. O que não sc comprcende é ver Lucien Febvrc se perguntar, em 1943: "Qual foi o verdadeiro papel, na evolução da cultura européia, desse humanismo italiano...? Foi o "promotor" no terreno intelectual, como a arte italiana passava por haver sido no terreno artístico? Não seria conveniente recolocar os termos do problema e se perguntar se a França -a França que conheceu tão cedo, já no século XII, uma vida buliçosa e desenfreada; a França que soubc expressar com tanto brio seu individualismo religioso no pensamento dos místicos ou no nacionalismo disciplinado mas irrequieto de Abelardo; a França que lia os textos antigos nas escolas catedralícias de uma forma que os latinistas do Quattrocento não teriam desaprovado...perguntar se não foi a França, na verdade, a diretora de orquestra? E se é certo que os escultores de Reims, de Chartres inclusive, esperaram os de Pisa para ver a naturcza com os olhos dos antigos, se não se poderia ver, ao fim e ao cabo, na Divina Comédia uma poderosa síntese do saber parisiense, em Petrarca o último dos grandes trovadores e $\mathrm{cm}$ Boccaccio o autêntico herdeiro da Idade Média francesa e de sua veia realista?"(p.112).

Nāo é inacreditável? Febvre supera, e muito, este outro delírio francês sobre o tcma, o do filósofo Etienne Gilson, que em 1932, escrevia: "A diferença entre o Renascimento e a Idade Média nāo é uma diferença por excesso mas por falta. O Renascimento, tal como nos foi descrito, não é a Idade Média mais o homem, mas a Idade Média menos Deus, $\mathrm{c}$ a tragédia é que ao perder Deus o Renascimento iria perder o próprio homem"(PANOFSKY, 1960, p.24).

Mas, antes de mostrar o absurdo, o disparate, para dizer o mínimo, da afirmação de L. Febvre, já que, como se verá, foram precisamente Petrarca e Boccaccio os que por primeiro criaram consciente- mente o Renascimento, que o vivenciaram ao mesmo tempo como ruptura e como tradição, voltemos a Burckhardt, e a Tocqueville.

Burckardt, ao contrário de Michelet e de Febvre, soube ver e interpretar o Renascimento como uma ruptura e como uma criação italiana. Em uma conhecida passagem de A Cultura do Renascimento na Itália, no início da segunda parte, intitulada "O Desenvolvimento do Indivíduo", Burckhardt assim caracteriza o fenômeno: "Na Idade Média, ambas as faces da consciência -aquela voltada para o mundo exterior $\mathrm{e}$ a outra, para o interior do próprio homemjaziam, sonhando ou em estado de semivigília, como que envoltas por um yéu comum. De fé, de uma prevenção infantil c de ilusão tecera-se esse véu, através do qual se viam o mundo e história com uma coloração extraordinária; o homem reconhecia-se a si proprio apenas enquanto raça, povo, partido, corporação, família ou sob qualquer outra das demais formas do coletivo. Na Itália, pela primeira vez, tal véu dispersa-se ao vento; desperta ali uma contemplação e um tratamento objetivo do Estado e de todas as coisas deste mundo. Paralelamente a isso, no entanto, erguc-se também, na plenitude de seus poderes, o subjetivo: o homem torna-se um individuo espiritual e se reconhece enquanto tal."(p.111).

Pode-se, evidentemente, criticar Burckhardt e recusar sua interpretação, como o fizeram, entre tantos outros, o próprio Huizinga, que, no entanto, sabia admirá-lo: "A estrutura deste incomparável modelo de síntcse histórico-cultural é sólida e harmônica tal como a de uma obra-prima renascentista"'(p.233). Este feliz paralelo que Huizinga estabelece entre o sujeito, a obra de Burckhardt, e o objeto, o Renascimento, é tanto mais interessante porquanto, como bcm notou Perry Anderson: "No geral a literatura moderna sobre o Renascimento italiano é curiosamente limitada e árida: como se a própria escala das criaçōes do Renascimento de alguma maneira tivesse paralisado os historiadores que o abordaram". Para P. Anderson 
- livro de Panofsky, Renascimento e Renascimentos na Arte Ocidental, "é a única grande obra histórica sobre a renovaçăo da Antigüidade digna deste objeto... O livro de Panofsky tem uma orientação puramente estética: toda a história econ6mica, social e política fica de fora de seu proposito. Mas por sua qualidade e método, determina a pauta de trabalho que resta por fazer neste domínio. Acima de tudo, Panofsky leva mais a sério do que jamais se fez a relação retrospectiva do Renascimento com a Antigüidade, e pela qual a época tomou consciéncia de si mesma" (1974, p.171-2).

Citamos, longamente, de um lado, porque é precisamente sobre este aspecto do Renascimento que aqui se tratarí, ou scja, da sua relaçāo com a Antigüidade, com o passado, portanto, como tradição, $\mathrm{e}$ a autoconsciência que desse fato decorre, portanto, como ruptura com a Idade Média; e de outro lado, porque o livro de Panofsky nos servirá de modelo e guia nesta empreitada.

Mas voltemos uma vez mais a Huizinga, Huizinga partiu da refutação da tese de Burckardt, do Renascimento como rompimento, para produzir sua propria obra-prima: O Declínio da lclade Média (1919). Assim, onde Burckhardt -olhando essencialmente para a Itália entre os séculos XIV e XVI, viu o nascimento do novo, do Renascimento, Huizinga, olhando essencialmente para a França e os Países Baixos, no mesmo período, viu, ao contrário, a continuidade do velho, da Idade Média. É-se tentado, não obstante as diferenças, a aproximar mais ainda Huizinga, de Burckhardt, a vê-los como dois representantes de uma mesma tradição européia: humanista-cristã, liberal-conservadora, cosmopolita-erudita, à maneira de Erasmo de Roterdã. Só que enquanto o suíço vivendo no verão -triunfante- da civilização burguesa, foi procurar sua primavcra, o Renascimento, o holandês, vivendo no inverno -catastrofico- da primeira guerra mundial, foi procurar o outono da civilizaçāo medicval. No prefácio à primeira edição inglesa de seu livro, de 1924, declara Huizinga: "Mas na História como na Natureza, nascimento e morte estāo equilibrados entre si. A decadência de formas de civilização em adiantado estado de maturaçảo é tão sugestiva como o espetáculo do crescimento de novas formas. E sucede ocasionalmente que um período $\mathrm{em}$ que se tenha especialmente procurado o nascimento de coisas novas se revela de súbito como uma época de declínio e decadência".

Tocqueville, por sua vez, atribui ao Estado moderno, isto é, a monarquia francesa da época do Renascimento, que para ele começa no século XV, com Carlos VII, a iniciação do processo de centralização do poder que a Revolução francesa iria, não destruir, mas levar às suas últimas consequiências. Afirma Tocqueville: "É a realeza que nada mais tem em comum com a realeza medicval: possui outras prerrogativas, ocupa um outro lugar, tem um outro espírito, inspira outros sentimentos. É a administração do Estado estendendo-se por toda parte sobre os escombros dos poderes locais. É a hierarquia dos funcionários substituindo de mancira crescente o governo dos nobres. Todos esses novos podercs obedecem a procedimentos, seguem máximas que os homens da Idade Média ignoravam ou reprovavam e que sc relacionam com um eslado de sociedade do qual realmente não tinham a menor idćia"(p.62).

É sabido que uma vez iniciada a Revolução francesa, isto é. pelo menos desde o mês de julho de 1789, os revolucionários logo batizaram de "Antigo" o "Regime" que eles estavam pondo a baixo. Em suma, desde a Revoluçāo francesa, todos falam $\mathrm{cm}$ Antigo Regime para designar o pcríodo imediatamente a cla anterior. Mas ninguém antes de Tocqueville havia dado ao termo o estatuto de um conceito, de uma categoria histórica definida. Já foi notado que o Antigo Regime tem um momento preciso de falecimento, isto é, julho-agosto de 1789 , mas não tem um momento preciso de nascimento. Com o fim do Antigo Regime fecha-se um período histórico, a 
História Moderna, e começa outro, a História Contemporânea. Mas quando começa exatamente o Antigo Regime? No século XV? No XVI? Ou será, talvez, no XVII? Ninguém sabe.

Sabe-se que com ele, isto é, com o Antigo Regime, também começa a Idade Moderna, em algum momento, entre os séculos XV e XVI. Ora, não há como não constatar a ironia de que o que era moderno no século XV/XVI, tornou-se antigo no século XVIII. Como se a inefável aurora do Renascimento, ao invés de dar lugar a um novo dia, diferente dos anteriores, tivesse dado lugar a um dia igual aos outros, e, portanto, ao invés da entrada em cena do capitalismo e da sociedade burguesa se assistisse ao retorno do feudalismo e da sociedade aristocrática. Daí a razão de alguns historiadores falarem $\mathrm{cm}$ refeudalizaçāo e outros em "traição da burguesia", ao se referirem a csse período e fenômeno histórico. Mas essa nāo é a única ironia. Porque com o Renascimento, como se verá, o moderno torna-sc velho, isto é, gótico, medicval, c o antigo, isto é, greco-romano, torna-se novo e clássico.

Seja como for, a grande façanha de Tocqueville, para gáudio de todos os conservadores, de todos quantos não gostam da Revolução francesa, foi ter invertido os termos conceituais, os lugares da continuidade e da ruptura na História Moderna. Na tese de Tocqueville, a Revoluçāo, ao levar a termo a obra de centralização do Antigo Regime, representa uma continuidade, e o Antigo Regime, ao criar um novo tipo de poder, representa uma ruptura. Assim, para Tocqueville, como bem notou o historiador François Furet (1978), a Revolução foi uma ruplura nas consciências, mas não na realidade, ao passo que, se levarmos o paralelo até o fim, no início da Idade Moderna, com a monarquia renascentista, houve uma ruptura na realidade sem que os sujeitos dela tivessem tido consciência. "Ouso afirmar, escreve Tocqueville, que dcsde o dia em que a nação cansada pelas longas desordens que acompanharam a catividade do rei João e a loucura de Carlos VI, permitiu aos reis estabelecer um imposto geral sem sua participação e em que a nobreza teve a covardia de permitir que taxassem o terceiro estado contanto que a isentassem ela própria, a partir deste dia foi semeado o germe de quase todos os vícios e quase todos os abusos que deformaram o antigo regime durante o resto de sua vida e acabaram causando violentamente sua morte"(p.111).

Registre-se, en passant, que, para Tocqueville, cuja obsessāo é a liberdade política, esta, ao invés de vir ao mundo com a revolução burguesa, entendida aqui tanto como modalidade quanto como época, (isto é, que se inicia durante o Renascimento e a Reforma, passa pelas duas Revoluçōes inglesas do século XVII e se completa com a Revolução francesa) como é o caso para os historiadores franceses da Restauração, Guizot, Thierry, Mignet, e também, e não menos, para Marx e Engels -para o aristocrata Tocqueville, ela, a liberdade, deita suas raízes no feudalismo, na Idade Média, porque ela é quase que um atributo, um apanágio da nobreza, da aristocracia. Ponto de vista aliás que já se cncontra em Montesquieu a quem Tocqueville tanto admirava. Com efeito, em Do Espirito das Leis (1747), lê-se: "Destruindo o império grego, os tártaros implantaram nos países conquistados a servidão e o despotismo; os godos, conquistando o império romano, implantaram $\mathrm{cm}$ loda parte, a monarquia e a liberdade... elas (as naçōes do norte da Europa) foram a fonte da liberdadc da Europa, ou seja, de quase toda a liberdade que cxiste atualmente entre os homens".

Mas, de Petrarca a Maquiavel, passando por Lorenzo Valla, Pico della Mirandola e tantos outros humanistas, uma interpretação como esta não poderia parecer menos do que ofensiva, chocante, absurda. Com efeito, Rousseau, fazendo eco do republicanismo clássico, defendido por muitos humanistas, afirma cm Do Contrato Social (1762): "A idéia de representantes é moderna: vern-nos do governo feu- 
dal, desse governo iníquo e absurdo no qual a espécie humana so se degrada e o nome de homem cai em desonra".

Voltemos a Tocqueville, uma última vez. Ao sustentar que a Revolução francesa teria sido uma ruptura nas consciências e, nāo na realidade, portanto, uma ilusão, um auto-engano, uma ideologia, ele está, neste sentido, curiosamente, com a mesma posição apresentada por Marx e Engels em A Ideologia Alemã (1845): "não partimos do que os homens dizem, imaginam, concebem, nem tampouco daquilo que eles são nas palavras, no pensamento, na imagina. ção e na concepção de outros, para em seguida chegar aos homens de carne e osso; não, partimos dos homens em sua atividade real; é a partir também de seu processo de vida real que concebemos o desenvolvimento dos reflexos e ecos ideológicos deste processo vital"

Ora bem, se não há como discordar do procedimento proposto por Marx e Engels, é preciso, contudo, saber, como bem notou Panofsky, no seu luminoso Renascimento e Renascimentos naArte Ocidental, que: "Em história... não é só o que os homens fazem que conta mas também o que eles pensam, sentem e crêem: as emoçōes e as convicções subjetivas nāo são mais facilmente separáveis das ações ou realizações objetivas que a 'qualidade' da 'quantidade"' (p.62-63)".

Seguindo Panofsky, veremos entāo que o que os humanistas do Renascimento "pensavam, sentiam e

3. Concepção praticamente idêntica à de Panofsky encontra-se em Huizinga, quando, referindo-se aos cronistas do século XV afirma: "Portanto, o erro, pode replicar-se, é deles, e a nossa concepçx̃o da ldade Média está correta. Assim seria se para compreender o espírito de uma época bastasse conhecer as forças reais e ocultas e nđ̃o também os seus caprichos, ilusões e erros. Mas para a história da civilizą̧ăo as ilusōes ou opiniōes de uma época têm o valor de fatos reais"(1919, p.54). acreditavam", constituiu um extraordinário, maravilhoso, mo(vi)mento de realização. "Realização salienta Panofsky - no duplo sentido inglés de 'tornar-se consciente' e 'tornar-se real' "'(p.27). Realização vivida simultaneamente como um retorno a uma tradição passada, a Antigüidade clássica, e como um rompimento com uma tradição presente, a Idade Média gótica.

Note-se a ironia, para nảo dizer paradoxo, decorrente do fato de que ao escolherem e adotarem conscientemente uma tradição, uma autoridade, situada no passado, os renascentistas estavam nฮo apenas restabelecendo uma continuidade, uma tradição, mas estavam, na realidade, realizando um rompimento, uma ruptura com a tradiçăo, com a autoridade viva até aquele momento dominantc.

Tudo começa na primeira metade do sćculo XIV, no Trecento, com Petrarca. Com Petrarca porque, como foi reconhecido pelos próprios contemporâneos, a idéia duma 'revivescência sob a influência dos modelos clássicos' foi, pela primeira vez, por ele concebida e formulada. Depois de visitar Roma, e ficar impressionado com suas ruínas, Petrarca deu-se conta do contraste entre um passado de grandeza e um presente deplorável e, de acordo com Panofsky, "elaborou uma nova versão da história". Em outras palavras, Petrarca foi o primeiro a olhar para a antiga Roma pagã, como uma era de luz e esplendor, e para a Roma recente, cristã, como uma era de trevas e de decadência. O primeiro, portanto, a se dar conta do intervalo que existia entre a Antigüidade romana (antiquitas), vista como passado e tomada como modelo, e a realidade presente (media-etas), repudiada. Para Panofsky, "ao afirmar que os Romanos pagāos é que tinham caminhado na luz e os Cristãos nas trevas, Petrarca revolucionou a interpretação da história não menos radicalmente do que Copérnico que, duzentos anos mais tarde, haveria de revolucionar a interpretação do universo físico" (p.30). 
A seguir, em meados do mesmo Trecento, Boccaccio estende ao domínio da pintura o que Petrarca havia iniciado mas limitado ao domínio da poesia, da linguagem. No Decameron de Boccaccio lê-se: "o gênio de Giotto era duma tal excelência que nada existia na natureza... que ele não fosse capaz de representar por meio do estilete, da pena ou do pincel com uma tal verdade que o resultado mais parecia uma obra da natureza que uma sua imitação. Pelo que o sentido humano da vista facilmente se deixava enganar pelas suas obras, tomando por realidade o que era apenas pintura. E assim fez ele regressar à luz esta arte que durante tantos séculos estivera sepultada sob os crros de alguns que pintaram para agradarem aos olhos do ignorante e nāo para satisfazercm a inteligência dos sábios, devendo ser justamente considerado como uma das luzes da glória florentina..." (PANOFSKY, p.32).

Como se vê, enquanto Petrarca lançava o programa de um "regresso à Antigüidade", Boccaccio, se dava conta de que Giotto, inaugurava com sua pintura, um "regresso à natureza", e ambos, regresso à Antigiiidade e regresso à natureza, acabariam por sc reconciliar, isto ć, a natureza passava a ser identificada à Antigüidade e esta à natureza. Na feliz formulaçāo, posterior, de Goethe: "A Antigüidade faz parte da natureza e mesmo, sempre que nos emociona, da natureza natural" (Idcm, p.55).

No século XV, no Quattrocento, Lorenzo Valla, escrevia: "Não sei porque ć que as artes mais próximas das artes liberais -a pintura, a escultura... e a arquitetura- tiveram um declínio tão profundo e tão prolongado, que foi quase uma morte, juntamente com a própria literatura; nem porque ć que nestes tempos sc levantaram c ressuscitaram, a ponto de existir agora uma tão rica seara simultancamente de cxcelentes artistas e de cxcelcntes cscritores" (Idem, p.37).

Mas se Lorenzo Valla declara não saber porque as artes haviam conhecido um declínio tão profundo e prolongado, Lorenzo Ghiberti, formula, na mesma época, a seguinte interpretação: "Nos tempos do Imperador Constantino e do Papa Silvestre ganhou ascendência a fé cristã. Com a violenta perseguição feita à idolatria, foram mutiladas e destruídas todas as estátuas e pinturas embelezadas com tanta nobreza e dignidade antiga e perfeita, perecendo ao mesmo tempo os livros e os tratados bem como as regras que tinham servido de guias a cssa gentil $c$ notabilíssima arte" (Idem, p.49).

E pouco antes de Ghiberti lamentar a perda dos tratados antigos, que, ele imaginava, conteriam as regras que deveriam governar as artes, Leone Batista Alberti apresentava, em 1435, seu Tratado sobre a Pintura que iria servir como uma espécie de manifesto, de programa, da arte renascentista. O pintor, afirma Alberti, "deverá, antes de mais, esforçarse para que todas as partes se harmonizem entre si, o que acontecerá se todas elas, pela quantidade, pela função, pela espécie, pela cor e por todos os outros aspectos, se harmonizarem numa mesma e única beleza" (Idem, p.50).

O mesmo Alberti, também escreveu De Estátua e De Arquitetura, e, nesta última, lê-se: "Os gregos, tentando superar $\mathrm{cm}$ gênio $\mathrm{e}$ qualidade as rjcas construçōes dos asiáticos e dos egípcios, distinguiam entre o bom e o menos bom e recorreram à natureza, seguindo as intençōes desta em vcz de misturarem coisas incongruentes, observaram como os princípios masculino e feminino produzem uma terceira coisa melhor e estudaram o desenho e a perspectiva" (Idem, p.52-53).

Finalmente, com Vasari, no século XVI, no Cinquecento, precisamente $\mathrm{cm} 1550$, atinge-se um "novo nível de consciência histórica e sistemática", afirma Panofsky. "Vasari foi o primeiro a apresentar as destruiçōes dos bárbaros $\mathrm{c}$ o 'arrebatado zclo da nova religião cristã' como as causas conjuntas de uma única c mesma catástrofe, foi o primeiro a ver o 'renascimento da arte' como um fenômeno total e a designálo pelo nome colctivo de "la rinascita"' (p.56). Vasari 
foi também responsável por superar a confusão terminol6gica então existente. Assim, por exemplo, enquanto Cennino Cennini afirmava que Giotto fizera da pintura uma arte "moderna". António Filarete, referia-se às velhas construçðes dos arquitetos transalpinos (ou seja, ao gotico) como moderni e às construçōes feitas segundo o novo estilo do 'Renascimento' como antichi ou alla romana e alla antica. Vale a pena citá-lo no original: "Ancora a me solevano piacere questi moderni; ma poi chi'io cominciai a gustare questi antichi, mi sono venuti in odio quelli moderni" (Idem, P.41).

Como se vê os humanistas e artistas italianos foram ao mesmo tempo nāo só artistas ou filólogos, mas também críticos, teóricos e intérpretes do seu movimento e do seu tempo. A expressão de Manetti sobre Brunelleschi, segundo a qual este estava dotado de um "buono occhio mentale", expressa admiravelmente o nível de consciência alcançado no Renascimento Como bem assinalou Panofsky, "No Renascimento italiano, o passado clássico começou a ser olhado a partir de uma distância fixa, comparável à 'distância entre o olho e o objeto' no que constitui uma das invenções mais características desse mesmo Renascimento, a saber, a perspectiva; como nesta, essa distância impedia um contato direto -devido à interposição de um 'plano de projeção' ideal- mas permitia uma visão total c racionalizada" (p.153-154).

Esta consciência do humanista renascentista, dotado de visão perspectiva, aparece brilhantemente expressa por Maquiavel na dedicatória de seu $O$ Príncipe ao magnifico Lorenzo de Medici quando afirma: "os que desenham os contornos dos países se colocam na planície para considerar a natureza dos montes, c para considerar a das planícics ascendem aos montes, assim também para conhecer bem a natureza dos povos é necessário ser príncipe, e para conhecer a dos príncipes é neccssário ser do povo". Pouco antes, na mesma dedicatória, Maquiavel tam- bém declara que nada the é mais caro do que o "conhecimento das ações dos grandes homens apreendido por uma longa experiência das coisas modernas e uma contínua liçāo das antigas".

Em outras palavras, o Renascimento sabia que cra renascentista ao passo que a Idade Média, como já foi dito, nunca soube que era medieval. Panofsky conclui sua interpretação sobre o Renascimento, com esta belíssima imagem: "A Idade Média deixara a Antigüidade por enterrar, ora galvanizando ora exorcizando o seu cadáver. O Renascimento ficou a chorar junto ao seu túmulo tentando ressuscitar-lhe a alma... As almas ressuscitadas são intangiveis mas têm o privilégio da imortalidade $\mathrm{c}$ da omnipresença. Por isso, o papel da antigüidade clássica depois do Renascimento é um tanto evasivo mas, também, omnipresente -c apenas mudará quando mudar a nossa própria civilização" (p.160).

Para melhor iluminar estas reflexōes sobre o Renascimento enquanto tradição $c$ ruptura, e, também, e não menos, enquanto modernidade parcial, ou limitada, tracemos um rápido paralclo entre dois gigantes, dois clássicos da política, Maquiavel e Hobbes. Um, por ser o primeiro moderno, embora não totalmente moderno, o outro, por ser o primeiro completamente moderno.

Considera-se Maquiavel um pensador político moderno por ter sido cle o primeiro a pensar a política como uma atividade, um campo, separado $\mathrm{e}$ independente da moral e da religião. Com efeito, em $O$ Principe lê-se: "Nas açōes de todos os homens, máxime dos príncipes, onde não há tribunal ao qual se possa recorrer, o que importa é o êxito bom ou mau. Procure, pois, um príncipe vencer e conservar o Estado. Os meios que empregar serão sempre julgados honrosos $c$ louvados por todos, porque o vulgo é levado pelas aparências e pelos resultados dos fatos consumados, e o mundo é constituído pelo vulgo".

Compare-se agora esta visão maquiavélica, laica, e portanto, já moderna, com a visão erasmiana, cris. 
tã, e portanto, ainda medieval, da política. Em $O$ Elogio da Loucura, escrito em 1511, apenas dois anos antes de $O$ Principe, Erasmo, afirma: “...deverá ele (o príncipe) mais cedo ou mais tarde, apresentar-se perante o tribunal do Rei dos reis, no qual the serão pedidas contas exatas de todos os seus menores atos, sendo ele julgado com rigor proporcional à extensão do seu domínio".

Como se vê, Erasmo, o mais completo humanista, a major glória do Renascimento, ainda é, em termos de política (e de religião, ao não ter aderido à Reforma protestante), um homem.medieval ou prémoderno. Contudo, e paradoxalmente, o olhar moderno de Maquiavel sobre a política decorre mais do seu amor pelo passado clássico do que da sua observação e experiência do presente. Como todos os humanistas, Maquiavel estava imbuído de uma ardente paixão pela Antigüidade clássica.

Talvez em nenhum outro renascentista se encontre uma declaração de fé, de amor pelos clássicos, como a que Maquiavel fez na carta a seu amigo Franceso Vettori, de 1513, onde descreve seu cotidiano no exílio e onde se lê: "Chegando a noite, de volta a casa, entro no meu cscritório: e na porta dispo as minhas roupas cotidianas, sujas de barro e de lama, e visto as roupas de corte ou de cerimônia, e, vestido decentemente, penetro na antiga convivência dos grandes homens do passado; por cles acolhido com bondade, nutro-me daquele alimento que é o único que me é apropriado e para o qual nasci. Não me envergonho de falar com cles, e lhes pergunto da razão das suas açōes, e cles humanamente me respondem; e não sinto durante quatro horas aborrecimento algum, esqueço todos os desgostos, não temo a pobreza, não me perturba a morte transfundome neles por completo"

Dizíamos há pouco que todos sabem que Maquiavel é o primeiro pensador moderno da política, mas, deve-se acrescentar, nem todos sabem que Maquiavel, não foi, como em geral se pensa, um homem destituído de moral e ética. Maquiavel criticou a moral e a ética da religiāo cristā porque esta era aos seus olhos incompatível com as necessidades da vida política, fosse esta dominada pelo príncipe, fosse pelos cidadãos. Vida política que ele via como sendo a mesma ou igual a que existira na Antigüidade clássica. Assim, à moral cristā, ele opunha a moral republicana clássica, da Antigüidade. Só um homem como Maquiavel, dotado de uma ardente, intensa paixão ético-política, poderia ser o autor da seguinte frase das Histórias Florentinas: "Eles preferiram a grandeza da cidade à salvaçāo de suas almas" (Citada por Max Weber em A Políica como Vocação, 1919).

Mas, exatamente por que Maquiavel tinha a sua consciência c a sua visão, o seu buono occhio mentale, para retomar a expressão de Manetti, (in)formado pelo republicanismo clássico, isto é, antigo, que ele pôde ser, a um só tempo, moderno e não moderno. Moderno porque, graças aos antigos pôde ver como a moral religiosa tem que estar subordinada à política e não a política à religião, como queria a lgreja católica.

Não moderno porque, devido aos antigos, e ao contexto histórico italiano, não pôde se dar conta de que enquanto a Itália chegava, em termos políticos, a uma espécie de beco histórico sem saída, fora dela, em Portugal, na Espanha, França e Inglaterra, estava surgindo um novo tipo de monarquia, de Estado, fruto de uma nova articulaçāo com a nobreza, por um lado, e com a Igreja, por outro, destinado a se transformar no instrumento da passagem do feudalismo ao capitalismo, na concepçāo marxista, e no instrumento da passagem da aristocracia para a democracia, na concepção tocquevilliana, mas, -seja como for, para realizar, e completar, a primeira modernidade européia.

Modernidade da qual Hobbes foi o maior expoente c tcórico. Como se sabe o absolutismo político de Hobbes é tão laico quanto é laico o absolutismo político que Maquiavel advoga em $O$ Príncipe. 
Ambos nada tiveram a ver com o direito divino dos reis. Mas enquanto um tinha o seu buono occhio nentale governado pelo passado, o outro o tinha governado pelo presente, e só pelo presente. Em Hobbes. ao contrário de Maquiavel, não existe nenhuma reverência, nenhuma ligaçāo especial com os clássicos (embora cle os conhecesse mais ainda do que o proprio Maquiavel os conhecia; bastando lembrar aqui que Hobbes traduziu A História da Guerra do Peloponeso, de Tucídides, do grego para o inglês).

Na "Introdução" de seu Leviatã (1651), Thomas Hobbes declara: "há um ditado que ultimamente tem sido muito usado: que a sabedoria não se adquire pela leitura dos livros, mas do homem"(grifos do autor). Pode-se dizer que na obra de Hobbes a crítica aos clássicos é uma nota sempre vibrada. Vejase, para dar mais um exemplo, essa passagem irônica: "Se Tito Lívio afirma que uma vez os deuses fizeram uma vaca falar, e não o acreditamos, não estamos com isso retirando nossa confiança a Deus, mas a Tito Lívio"

Como bem notou Norberto Bobbio (1979), Hobbes é o iniciador do jusnaturalismo político e do tratamento racional do problema do Estado. Foi o criador de um método "gcométrico", "o qual pres. cindindo de tudo o que podem ter dito os autores precedentes e não levando em consideração o ensinamento da história, busca o caminho de uma reconstrução meramente racional da origem e do fundamento do Estado" (p.36). E, sempre segundo Bobbio, "Hobbes faz tabula rasa de todas as opiniōes anteriores e constrói sua teoria sobre bases sólidas, indestrutíveis, do estudo da natureza humana e das necessidades que ela expressa, bem como do modo de satisfazer tais necessidades" (p.37).

Nesse sentido, e paradoxalmente, embora Hobbes seja do século XVII, ele é mais moderno do que Rousseau, que é do XVIII. Por que Rousscau, ao contrário de Hobbes, embora menos do que Maquiavel, também incorporara na sua concepçāo da polí- tica e da democracia o republicanismo clássico. Pode-se sustentar que Rousseau foi o primeiro crítico do liberalismo e da burguesia, o primeiro a perceber que o homem moderno é um ser dividido, precisamente porque ele também quis ressuscitar a unidade perdida do homem; unidade que somente a Antigüidade clássica havia conhecido.

Mas voltemos, uma última vez, aos séculos de Hobbes e de Maquiavel, para lembrar que enquanto o último século do Renascimento, o XVI, foi, do ponto de vista econômico-social, um período de grandes avanços e transformaçōes, o primeiro século do Renascimento, o XIV, c o primciro século pósRenascimento, o XVII, foram períodos de crise geral, de regressão e encolhimento econômico. No cntanto, do ponto de vista intelectual, foi no século XIV, que começou o Renascimento, e com ele a modernidade. Modernidade que, contudo, permaneceu a meio caminho.

O Renascimento, como Janus, o deus romano, tinha duas cabeças e, paradoxalmente, nenhuma das duas, ou melhor, por causa das duas, não foi capaz de fazer nascer o chamado pensamento racional. científico e com ele a idéia de progresso c uma nova atitude e visão diante do homem, da naturcza e da história, e, em conseqúência, pclo menos no plano intelectual, de cristalizar a modernidade. Foi só no século XVII, no século de Hobbes, que isto aconteceu: curiosamente, $\mathrm{c}$ da mesma forma que o XIV, um século de crise geral, de regressão e encolhimento econômico, mas, no plano sócio-político, de consolidação da aristocracia e do absolutismo (cste último exccto na Inglaterra). Daí a razāo de não poucos historiadores considerarem, como já foi dito, o século XVII, como um século marcado por um verdadeiro processo de refeudalizaçāo.

Como se viu, abordar o problema da tradiçāo $c$ continuidade, e da ruptura c mudança, na primeira modernidadc européia, isto é, entre os séculos XIV e XVIII, entre o Renascimento e a Revoluçăo fran- 
cesa, entre Burckhardt e Tocqueville, é, ao mesmo tempo, uma tarefa complexa $\mathrm{e}$ fascinante. Fascinante porque trata-se de uma aventura intelectual que, para o bem ou para o mal, é responsável por ludo que somos. E complexa porque, como vimos, as rupturas e as continuidades não acontecem de mancira regular e uniforme, e tem ritmos próprios conforme

\section{Bibliografia}

ANDERSON, Perry. Limhagens do Estado Absolutista. Porto. Afrontamento, 1984.

BOBBIO. Norberto e BOVERO, Michelangelo. Sociedude e Estado na Filosofia Políitca Moderna. São Paulo, Brasiliense, 1986.

BURCKARDT, Jacob. A Cultura do Renascimento da hilia. Såo Paulo, Companhia das Letras, 1990.

ERASMO. O Elogio da Loucura. São Paulo, Abril, Col. Pensadores.

FEBVRE, Lucien. Erasmo, la Contrareforma y el Expiritu Moderno. Barcelona, Orbis, 1985.

FURET, François. Pensando A Revoluçäo Francesa. Rio de Janeiro. Paz e Terro. 1989.

GAY. Peter. O Estilo na História. São Paulo. Companhia das Letras, 1990.

HOBBES. Leviatã. São Paulo, Abril, Col. Pensadores. se trata das consciências e das instituiçōes, do mental c do material. "Na história como na fisica", para citar uma última vcz a Panofsky, "também o tempo É função do espaço e a própria definição de um período como uma fase marcada por uma 'mudança de direção' implica, simultaneamente, continuidade e ruptura"(p.20).

HUIZINGA, Johan. "Il Problema del Rinascimento", in: La Mia Vita Alla Storia E Alıri Saggi. Bari. Laterza, 1967.

MAQUIAVEL. O Príncipe. São Paulo, Abril. Col. Pensadores. . O Declínio da ldade Média. São Paulo, Verbo-Edusp, 1978.

MARX e ENGELS. A /derlogia Alemä. Sāo Paulo, Alfa-Omega. MONTESQUIEU. Do Espirito das Leis. Sao Paulo, Abril, Col. Pensadores

PANOFSKY, Erwín. Renascimento e Renascimentos na Arte Ocidental. Lisbon, Presença, 1981.

ROUSSEAU. Do Comtrato Social. São Paulo, Abril, Col. Pensadores

TOCQUEVILlE. Alexis de. O Antigo Regime e a Revolugäo. Brasília, UNB, 1979.

WEBER, Max. Ciência e Política Duas Vocaşões. São Paulo, Cultrix, 1968 